\title{
Genetics of recurrent miscarriage: challenges, current knowledge, future directions
}

\author{
Kristiina Rull ${ }^{1,2}$, Liina Nagirnaja ${ }^{1}$ and Maris Laan ${ }^{1}$ * \\ ${ }^{1}$ Human Molecular Genetics Research Group, Institute of Molecular and Cell Biology, University of Tartu, Tartu, Estonia \\ ${ }^{2}$ Department of Obstetrics and Gynecology, Women's Clinic of Tartu University Hospital, Tartu, Estonia
}

Edited by:

Ryan Yuen, The Hospital for Sick

Children, Canada

Reviewed by:

Carolyn E. Banister, Brown University, USA

Fouad Janat, Siemens Diagnostics, USA

*Correspondence:

Maris Laan, Human Molecular

Genetics Research Group, Institute of Molecular and Cell Biology, University of Tartu, Riia 23, 51010 Tartu, Estonia. e-mail:maris.laan@ut.ee
Recurrent miscarriage (RM) occurs in 1-3\% of couples aiming at childbirth. Due to multifactorial etiology the clinical diagnosis of RM varies. The design of genetic/"omics" studies to identify genes and biological mechanisms involved in pathogenesis of RM has challenges as there are several options in defining the study subjects (female patient and/or couple with miscarriages, fetus/placenta) and controls. An ideal study would attempt a trio-design focusing on both partners as well as pregnancies of the couple. Application of genetic association studies focusing on pre-selected candidate genes with potential pathological effect in RM show limitations. Polymorphisms in $\sim 100$ genes have been investigated and association with RM is often inconclusive or negative. Also, implication of prognostic molecular diagnostic tests in clinical practice exhibits uncertainties. Future directions in investigating biomolecular risk factors for RM rely on integrating alternative approaches (SNPs, copy number variations, gene/protein expression, epigenetic regulation) in studies of single genes as well as whole-genome analysis. This would be enhanced by collaborative network between research centers and RM clinics.

Keywords: recurrent miscarriage, genetics, epigenetics, study design, research and clinical collaboration, association studies, omic's studies, placenta

\section{INTRODUCTION}

The occurrence of recurrent miscarriage (RM) has been estimated 1-3\% of couples attempting to bear children (Berry et al., 1995; Rai and Regan, 2006; Branch et al., 2010). While fetal chromosomal abnormalities are responsible for $70 \%$ of sporadic miscarriages (Ogasawara et al., 2000; Philipp et al., 2003; Menasha et al., 2005), they account for considerably smaller fraction of pregnancy losses in RM couples. Today, clinical practice includes testing of several factors potentially increasing the risk of (recurrent) miscarriage, e.g., parental chromosomal anomalies, maternal thrombophilic, anatomic, endocrine, and immunological disorders (Bricker and Farquharson, 2002; Christiansen et al., 2008; Branch et al., 2010; Tang and Quenby, 2010). At least 50\% of the RM cases have no deviations in any applied diagnostic test and are considered idiopathic, unexplained origin. In addition to clinical, environmental, and life-style risk factors, there is a growing evidence that RM has also genetic susceptibility. A review of initial observations indicated two to sevenfold increased prevalence of RM among first-degree blood relatives compared to the background population (Christiansen, 1996). Population-based register studies showed that overall frequency of miscarriage among the siblings of idiopathic RM is approximately doubled compared to general population (Nybo Andersen et al., 2000; Kolte et al., 2011). A recent genome-wide linkage scan using sibling pairs with idiopathic RM confirmed heterogeneity of contributing genetic factors (Kolte et al., 2011).

Unexplained RM is a stressful condition for a couple and supportive care is currently the only assistance that can be offered. Still, early recognition of a potential risk to miscarriage and systematic monitoring has beneficial effect in increasing live birth rates in RM couples (Jauniaux et al., 2006; Branch et al., 2010; Tang and Quenby, 2010; Musters et al., 2011). Genetic and genomic studies of RM have three main purposes: (1) identify DNA/RNA-based markers exhibiting direct predictive value to a couple's risk to experience recurrent pregnancy losses; (2) capture the gene/protein expression profiles, pathways, and networks involved in (un)successful establishment of pregnancy; (3) apply hypothesis-based and hypothesis-free studies to pinpoint loci coding for novel non-invasive biomarkers applicable in clinical conditions for early pregnancy complications.

\section{CHALLENGES IN STUDY DESIGN TO INVESTIGATE GENETICS AND "OMICS" OF RM}

The design of genetic/"omics" studies to identify genes and biological mechanisms involved pathogenesis of RM is complex having several contradictory aspects regarding to the definition of phenotype, study objects, and functional effects to address (Figure 1).

\section{DISCREPANCIES IN DEFINITION OF THE RM PHENOTYPE}

Recurrent miscarriage is classically defined as the loss of three or more consecutive pregnancies before 20th gestational weeks (Berry et al., 1995; Jauniaux et al., 2006; Branch et al., 2010). Some experts consider two consecutive pregnancy losses sufficient for the diagnosis of RM because the recurrence rate and risk factors are similar to that after three losses (Branch et al., 2010). The faulty recall of the reproductive history, including or excluding the biochemical pregnancies (pregnancies documented only by a positive 


\section{RECRUITMENT STRATEGY}

SUBJECTS/

OBJECTS IN

FOCUS

MATERIAL FOR
(EPI)GENETIC
ANALYSIS

\section{Studies of families/sibships $\downarrow$ with RM}

Female family members
All family members

\section{Studies of affected cases} and non-affected

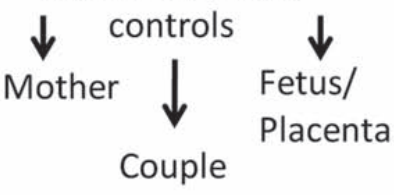

Blood DNA samples

- Case: woman/

couples with RM

- Control: woman/couples with proved fertility and without miscarriages
Fetal/placental tissue

- Case: women with RM

- Controls: at live birth delivery or from elective termination of normally proceeding pregnancy

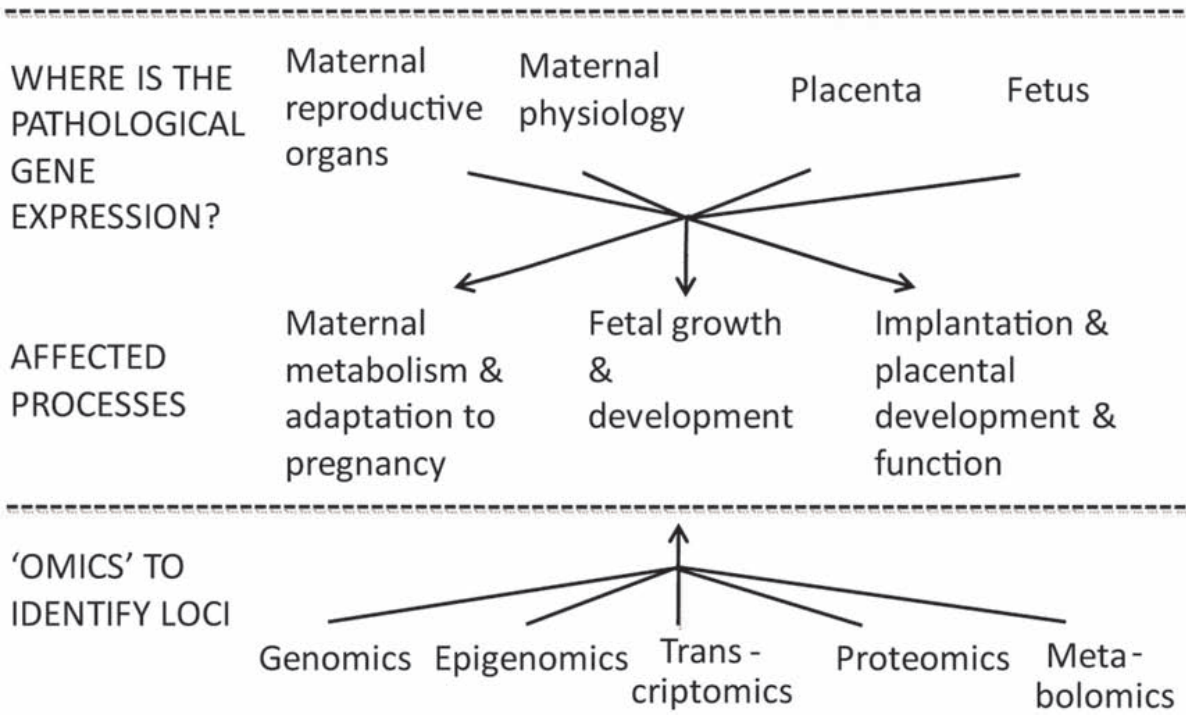

FIGURE 1 | Two broad options to investigate the inheritable component of recurrent miscarriage (RM) are family based linkage studies and comparison of unrelated cases and controls. For multifactorial diseases in adulthood the genetic association studies are superior compared to linkage analysis in pedigrees in terms of study design and power (Risch and Merikangas, 1996). In case of RM studies the addressed subjects/biological materials represent genetic materia from two generations: mother-father and offspring(s), both providing own advantages and limitations. The affected processes are located in different compartments (mother-placenta-fetus) and involve aberrations in gene/protein expression influencing both maternal and fetal organisms. urine or serum hCG test) and center-specific ascertainment biases cause discrepancies in setting the diagnosis of RM (Christiansen et al., 2005).

The couples with RM can be divided into subgroups according to their reproductive history: primary (no successful pregnancies), secondary (series of miscarriages after a live birth) and tertiary (three non-consecutive miscarriages) RM and they should be considered as separate entities representing probably different pathophysiological mechanisms leading to pregnancy loss. Immunological factors have been suggested to play a greater role secondary RM, especially after the first-born son (Christiansen et al., 2004; Nielsen, 2011). Non-immunological risk factors, e.g., factor V Leiden mutation, tend to be associated mainly with primary RM (Wramsby et al., 2000).
The analysis power of genetics/"omics" research depends on the quality of the clinical history and applied diagnostic tests. Currently, the cases of idiopathic RM have been considered as preferred phenotype for the genetics research. However, the definition of idiopathic RM based on exclusions of known risk RM factors is facilities- and study-dependent. The association and/or causality of an etiologic factor with RM varies from "doubtful" to "definite" complicating the definition of idiopathic RM (Christiansen et al., 2005).

In summary, as RM is characterized by multifactorial etiology and variable penetrance and clinical outcome of recognized risk factors, a consensus in the clinical and research community has to be reached what factors should be tested before defining a particular case as idiopathic addressed via genetic/genomic studies. 


\section{OPTIONS FOR DEFINING THE STUDY OBJECTS}

One of the most challenging questions in investigating the genetics of RM is defining the study object(s): female patient and/or couple with miscarriages, fetus, or placenta (Figure 1). In genetic/genomic context these options target three different genomes (mother, father, fetus/placenta) and four (epi)genomes (different for placenta and fetus). In addition, as the definition of RM is based on longitudinal data (several independent events), one should remember that each pregnancy and each conceptus is a unique genetic combination with unique epigenetic settings, unique environmental conditions regarding the efficiency of established maternal-fetal interphase, maternal nutrition, and health.

Several genes that regulate implantation, fetal and placental development, and maternal adaptation to pregnancy are synthesized by the fetus or the placenta, e.g., placental hormones as hCG, placental growth hormone and lactogen (Mannik et al., 2010; Nagirnaja et al., 2010; Newbern and Freemark, 2011). In this context, a placental (fetal) genome would represent an ideal RM case for (epi)genetic and genomic studies. However, there are severe limitations-the recruitment of couples/women at the RM event and difficulties in obtaining pure tissue material from the aborted fetus with no contamination with maternal cells. There are some genetic studied focused on RM compared to control placentas (e.g., HLA-C, HLA-G, p53, mtDNA mutations; Table 1) but the sample sizes in these studies never reach required statistical power.

As a solution, an ideal study would attempt a trio-design focusing on both partners of clinically well-described RM couples as well as aborted cases and live born children (as inner control) of the same couple. This would allow to directly address parentaland allele-specific gene expression or epigenetic modifications in placenta. The paternally inherited genetic factors contribute and combine with maternally inherited factors in the placental/fetal (epi)genome (Rull et al., 2008; Faridi and Agrawal, 2011; Uuskula et al., 2011). So far, most studies of couples have been limited to parental karyotyping, and in case of a structural chromosomal abnormalities their effect on couple's offsprings (Stephenson and Sierra, 2006; Franssen et al., 2011).

The identification of a suitable control group for women/couples with RM has its own great challenges. The ideal controls should be exposed to similar number of pregnancies at the same age of partners as the cases, and never experienced miscarriage. In a typical study the controls have been defined as women/couples with proven fertility when having at least one child, with limited information about their full reproductive history during the present or past partnerships. Delaying the childbirth until older reproductive age, the usage of contraceptive methods after birth of the one or two planned children, the change of co-habitant partners are frequent limitations for recruitment of the ideal control group.

\section{CHALLENGES IN LINKING THE GENETIC VARIANTS WITH THE PATHOLOGICAL FUNCTIONAL EFFECT}

A successful pregnancy can be achieved only via balanced dialog between mother and the fetus mediated through placenta. The pathologies may locate and influence physiology in different compartments (Figure 1). In maternal side, RM has been associated with genes responsible for impaired endometrial decidualization, apoptosis as well as inflammatory processes (Salker et al., 2010). Multiple (epi)genetic/genomic factors decrease sperm quality causing DNA damage and thus leading to poor fertilization, impaired embryo development and possibly to RM (McLachlan and O'Bryan, 2010; Brahem et al., 2011). The development of placenta and release of placentally expressed proteins strongly influence both the fetal and maternal metabolism during the pregnancy (Fowden et al., 2009; Lewis et al., 2012).

\section{GENETIC ASSOCIATION STUDIES OF RM: BIASES, CONTRADICTIONS, LIMITATIONS}

All conducted genetic association studies targeting RM have been designed as hypothesis-based candidate gene studies. The most frequently addressed genes in the context of RM are associated with the developing immunotolerance and inflammation and also with changes of maternal metabolism and blood coagulation (Table 1). Female partner of RM couple has been the most commonly addressed study subject.

The polymorphisms in almost 90 different genes have been investigated (Table 1). In most studies the association between a polymorphism and RM is negative, has not been replicated in follow-up studies or shows opposite results between studies. Inconsistencies may arise due to (i) differences in study design, definitions of RM and control group; (ii) focus on RM women instead of couples or placenta; (iii) low statistical power due to small sample size; (iv) ethnic difference in risk variants, populationspecific low-impact gene variants increasing RM risk in consort; (v) contribution of life-style and environmental factors on the pregnancy course; (vi) secondary pathways affecting protein translation/metabolism leading to discrepancies between genotype and respective protein levels, e.g., Factor XII, Protein Z (Iinuma et al., 2002; Topalidou et al., 2009).

Most popular clinically tested polymorphisms in RM patients are thrombophilia-associated factor $\mathrm{V}$ (Leiden factor) mutation, factor II (prothrombin) G20210A mutation and MTHFR C667T variant encoding the methylenetetrahydrofolate reductase enzyme with reduced activity. However, meta-analyses or large studies focusing on these factors in relation to RM risk have controversial results (Table 1). There is also uncertainty about prognostic implications of positive tests as full thrombophilia screen can produce abnormal results in $20 \%$ of women with uncomplicated obstetric histories (Branch et al., 2010; Tang and Quenby, 2010).

Another set of thoroughly investigated polymorphisms providing contradictory results in association with $\mathrm{RM}$ are in genes involved in inflammation (e.g., IL1B, IL6, IL10, IFN $\gamma$, TNF $\alpha$; Table 1). The balance of locally produced pro-inflammatory and anti-inflammatory cytokines was suggested to be critical for successful pregnancy (Choi and Kwak-Kim, 2008). It was proposed that a spectrum of thrombophilic and inflammation related genetic variants rather than single polymorphisms shape the cumulative risk of RM (Rey et al., 2003; Jivraj et al., 2006; Christiansen et al., 2008).

The immunological mechanisms responsible for the development of the tolerance to semi-allogeneic fetal "graft" by the maternal immune system has been the third attractive target for genetic studies. Positively, a majority of association studies with 
Table 1 | Genes targeted to genetic association studies in relation to RM risk.

\begin{tabular}{|c|c|c|c|c|c|c|}
\hline \multirow[t]{2}{*}{ Gene name } & \multicolumn{3}{|c|}{ Genetic association $^{a}$} & \multicolumn{2}{|c|}{$\begin{array}{l}\text { Main effect of the } \\
\text { polymorphism }\end{array}$} & \multirow[t]{2}{*}{ Key reference } \\
\hline & $\begin{array}{l}\text { Single } \\
\text { study }\end{array}$ & $\begin{array}{l}\text { Meta- } \\
\text { analysis }\end{array}$ & $\begin{array}{l}\text { Study } \\
\text { cases }^{b}\end{array}$ & Mother & $\begin{array}{l}\text { Fetus/ } \\
\text { placenta }\end{array}$ & \\
\hline \multicolumn{7}{|c|}{ INFLAMMATION } \\
\hline IFNG & $\mathrm{Y} / \mathrm{N}$ & $\mathrm{Y} / \mathrm{N}$ & $\mathrm{F}$ & V & V & Bombell and McGuire (2008), Daher et al. (2003) \\
\hline $\operatorname{IL1B}$ & $\mathrm{Y} / \mathrm{N}$ & $\mathrm{Y} / \mathrm{N}$ & $\mathrm{F}$ & V & V & Bombell and McGuire (2008) \\
\hline ILIRN & $\mathrm{Y} / \mathrm{N}$ & & $\mathrm{F}$ & V & V & Choi and Kwak-Kim (2008) \\
\hline $\mid L 1 R 1$ & $N$ & & $\mathrm{~F}$ & V & V & Traina et al. (2011) \\
\hline IL4 & $N$ & & $\mathrm{~F}$ & V & V & Kamali-Sarvestani et al. (2005), Saijo et al. (2004a) \\
\hline IL6 & $\mathrm{Y} / \mathrm{N}$ & $\mathrm{Y} / \mathrm{N}$ & $\mathrm{F}$ & V & V & Bombell and McGuire (2008), Daher et al. (2003) \\
\hline IL 10 & $\mathrm{Y} / \mathrm{N}$ & $\mathrm{Y} / \mathrm{N}$ & $\mathrm{F}$ & V & V & Bombell and McGuire (2008), Daher et al. (2003) \\
\hline $\operatorname{lL} 12 B$ & $N$ & & $\mathrm{~F}$ & V & & Ostojic et al. (2007) \\
\hline IL 18 & $Y / N$ & & $\mathrm{~F}$ & V & V & Al-Khateeb et al. (2011), Naeimi et al. (2006) \\
\hline IL21 & Y & & $\mathrm{F}$ & V & $\checkmark$ & Messaoudi et al. (2011) \\
\hline$T N F \alpha$ & $\mathrm{Y} / \mathrm{N}$ & $N$ & $\mathrm{~F}$ & V & V & Bombell and McGuire (2008), Daher et al. (2003) \\
\hline$T N F \beta$ & $\mathrm{N}$ & & $\mathrm{F}$ & V & $\checkmark$ & Kamali-Sarvestani et al. (2005), Prigoshin et al. (2004) \\
\hline TNFR1 & $\mathrm{N}$ & & $\mathrm{F}$ & V & V & Yu et al. (2007) \\
\hline \multicolumn{7}{|c|}{ THROMBOSIS AND CARDIOVASCULAR SYSTEM } \\
\hline$A C E$ & $\mathrm{Y} / \mathrm{N}$ & & $\mathrm{F}$ & V & V & Goodman et al. (2009b), Zhang et al. (2011) \\
\hline$A C H E$ & Y & & $\mathrm{F}$ & V & V & Parveen et al. (2009b) \\
\hline$A G T$ & N & & $\mathrm{F}$ & & V & Goodman et al. (2009b), Hefler et al. (2002) \\
\hline ANXA5 & Y & & $\mathrm{F}$ & & V & Bogdanova et al. (2007), Miyamura et al. (2011) \\
\hline$A P O B$ & N & & $\mathrm{F}, \mathrm{C}$ & V & V & Hohlagschwandtner et al. (2003), Yenicesu et al. (2009) \\
\hline APOE & $\mathrm{Y} / \mathrm{N}$ & & $\mathrm{F}$ & V & $\mathrm{V}$ & Bianca et al. (2010), Goodman et al. (2009a) \\
\hline AT1R & $Y / N$ & & $\mathrm{~F}$ & V & $\mathrm{V}$ & Buchholz et al. (2004), Fatini et al. (2000) \\
\hline EPCR & $\mathrm{Y} / \mathrm{N}$ & & $\mathrm{F}, \mathrm{C}$ & & $\mathrm{V}$ & Dendana et al. (2012), Kaare et al. (2007) \\
\hline F2 & $\mathrm{Y} / \mathrm{N}$ & $\mathrm{Y} / \mathrm{N}$ & $\mathrm{F}, \mathrm{C}$ & V & 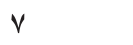 & Kovalevsky et al. (2004), Silver et al. (2010), Toth et al. (2008) \\
\hline F5 & $\mathrm{Y} / \mathrm{N}$ & $\mathrm{Y} / \mathrm{N}$ & $\mathrm{F}, \mathrm{C}$ & V & V & $\begin{array}{l}\text { Dudding and Attia (2004), Kovalevsky et al. (2004), Rey et al. (2003), } \\
\text { Rodger et al. (2010), Toth et al. (2008) }\end{array}$ \\
\hline$F G B$ & $N$ & & $\mathrm{~F}, \mathrm{C}$ & V & V & Goodman et al. (2006), Yenicesu et al. (2009) \\
\hline F12 & $\mathrm{N}$ & $N$ & $\mathrm{~F}$ & V & $\vee$ & Sotiriadis et al. (2007), Walch et al. (2005) \\
\hline$F 13 A$ & $\mathrm{Y} / \mathrm{N}$ & $N$ & $\mathrm{~F}, \mathrm{C}$ & V & V & Coulam et al. (2006a), Sotiriadis et al. (2007), Yenicesu et al. (2009) \\
\hline GPla & Y & & $\mathrm{F}$ & V & V & Gerhardt et al. (2005) \\
\hline GPIIla & $\mathrm{Y} / \mathrm{N}$ & & $\mathrm{F}, \mathrm{C}$ & V & 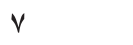 & Ivanov et al. (2010), Pihusch et al. (2001), Yenicesu et al. (2009) \\
\hline HMOX1 & Y & & $\mathrm{F}$ & & $\checkmark$ & Denschlag et al. (2004) \\
\hline$J A K 2$ & N & & $\mathrm{F}$ & V & V & Dahabreh et al. (2009) \\
\hline MTHFD1 & $N$ & & $\mathrm{~F}$ & V & V & Crisan et al. (2011) \\
\hline MTHFR & $\mathrm{Y} / \mathrm{N}$ & $\mathrm{Y} / \mathrm{N}$ & $\mathrm{F}, \mathrm{C}$ & V & V & Nelen et al. (2000), Ren and Wang (2006), Toth et al. (2008) \\
\hline$P A /-1$ & $\mathrm{Y} / \mathrm{N}$ & $N$ & $\mathrm{~F}$ & V & V & Buchholz et al. (2003), Goodman et al. (2009b), Sotiriadis et al. (2007) \\
\hline$P Z$ & $\mathrm{Y} / \mathrm{N}$ & & $\mathrm{F}$ & V & V & Dossenbach-Glaninger et al. (2008), Topalidou et al. (2009) \\
\hline SELP & Y & & $\mathrm{F}$ & V & & Dendana et al. (2011) \\
\hline TAFI & Y & & $\mathrm{F}$ & V & V & Masini et al. (2009) \\
\hline TGFB1 & $N$ & & $\mathrm{~F}$ & V & V & Prigoshin et al. (2004), von Linsingen et al. (2005) \\
\hline$T M$ & $N$ & & C & & V & Kaare et al. (2007) \\
\hline TSER & $N$ & & $\mathrm{~F}$ & V & V & Kim et al. (2006a) \\
\hline VEGF & $\mathrm{Y} / \mathrm{N}$ & & $\mathrm{F}$ & V & 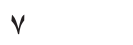 & Papazoglou et al. (2005), Traina et al. (2011) \\
\hline$Z P I$ & Y & & $\mathrm{F}$ & V & V & Alsheikh et al. (2012) \\
\hline \multicolumn{7}{|c|}{ DETOXIFICATION SYSTEM } \\
\hline AHR & $N$ & & $\mathrm{~F}$ & & V & Saijo et al. (2004b) \\
\hline ARNT & $N$ & & $\mathrm{~F}$ & & V & Sullivan et al. (2006) \\
\hline CYP1A1 & $\mathrm{Y} / \mathrm{N}$ & & $\mathrm{F}$ & & V & Parveen et al. (2010), Saijo et al. (2004b) \\
\hline CYP1A2 & $\mathrm{Y} / \mathrm{N}$ & & $\mathrm{F}$ & V & & Saijo et al. (2004b), Sata et al. (2005) \\
\hline
\end{tabular}


Table 1 | Continued

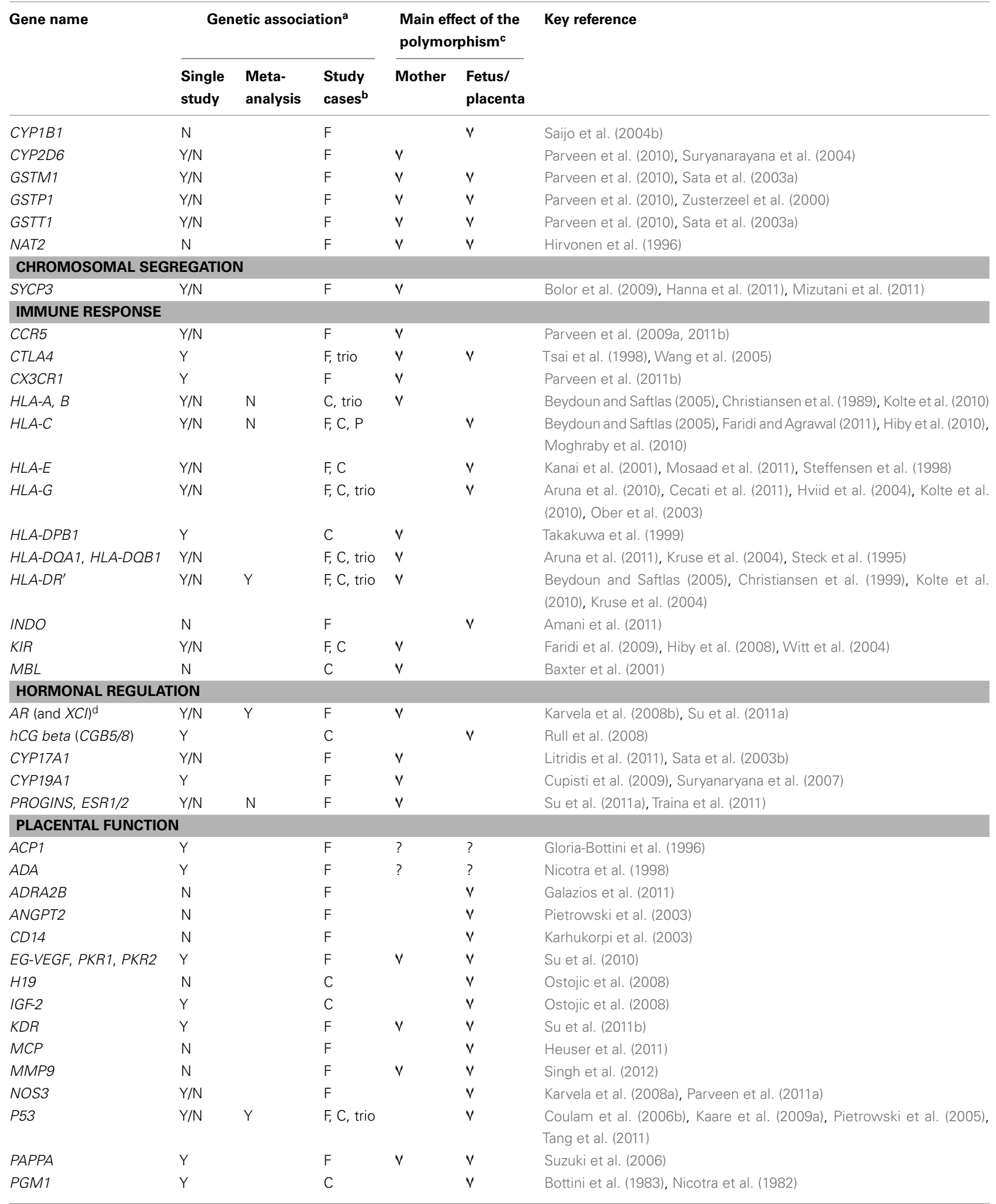




\section{Table 1 | Continued}

\begin{tabular}{|c|c|c|c|c|c|c|}
\hline \multirow[t]{2}{*}{ Gene name } & \multicolumn{3}{|c|}{ Genetic association $^{a}$} & \multicolumn{2}{|c|}{$\begin{array}{l}\text { Main effect of the } \\
\text { polymorphism }\end{array}$} & \multirow[t]{2}{*}{ Key reference } \\
\hline & $\begin{array}{l}\text { Single } \\
\text { study }\end{array}$ & $\begin{array}{l}\text { Meta- } \\
\text { analysis }\end{array}$ & $\begin{array}{l}\text { Study } \\
\text { cases }^{b}\end{array}$ & Mother & $\begin{array}{l}\text { Fetus/ } \\
\text { placenta }\end{array}$ & \\
\hline STAT3 & Y & & $\mathrm{F}$ & V & & Finan et al. (2010) \\
\hline TPH1 & $\mathrm{N}$ & & $\mathrm{F}$ & V & V & Unfried et al. (2001) \\
\hline \multicolumn{7}{|c|}{ MITOCHONDRIAL FUNCTION } \\
\hline Mutational burden & $\mathrm{Y} / \mathrm{N}$ & & $\mathrm{F}, \mathrm{C}$, trio & & V & Kaare et al. (2009b), \\
\hline
\end{tabular}

${ }^{a} Y$, positive association studies; $N$, negative studies.

${ }^{b} \mathrm{~F}$, female RM patients; C, RM couple; P, placenta; trio, parents + fetus/placenta.

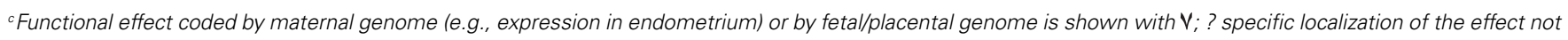
clearly determined.

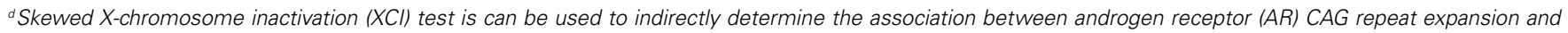
RM (Su et al., 2011a).

$A C E$, angiotensin I converting enzyme 1; $A C H E$, acetylcholinesterase; $A C P 1$, acid phosphatase 1; $A D A$, adenosine deaminase; $A D R A 2 B$, adrenergic, alpha-2B-, receptor; AGT, angiotensinogen; AHR, aryl hydrocarbon receptor; ANGPT2, angiopoietin 2; ANXA5, annexin A5; APOB, apolipoprotein B; APOE, apolipoprotein E; AR, androgen receptor; $A R N T$, aryl hydrocarbon receptor nuclear translocator; AT1R, angiotensin II type-1 receptor; CCR5, chemokine receptor 5; CD14, CD14 molecule; CGB5, chorionic gonadotropin, beta polypeptide 5; CGB8, chorionic gonadotropin, beta polypeptide 8; CTLA4, cytotoxic T-lymphocyte-associated protein 4; CX3CR1, chemokine (C-X3-C motif) receptor 1; CYP1A1, cytochrome P450, family 1, subfamily A, polypeptide 1; CYP1A2, cytochrome P450, family 1, subfamily A, polypeptide 2; CYP1B1, cytochrome P450, family 1, subfamily B, polypeptide 1; CYP2D6, cytochrome P450, family 2, subfamily D, polypeptide 6; CYP17A1, cytochrome P450, family 17, subfamily A, polypeptide 1; CYP19A1, cytochrome P450, family 19, subfamily A, polypeptide 1; EG-VEGF, endocrine-gland-derived vascular endothelial growth factor; EPCR, endothelial protein C receptor; ESR1, estrogen receptor 1; ESR2, estrogen receptor 2; F2, coagulation factor II/prothrombin; F5, coagulation factor V/factor V Leiden; F12, coagulation factor XII; F13A, coagulation factor XIII, A1 polypeptide; FGB, fibrinogen beta chain; GPla, platelet glycoprotein la; GPIIIa, platelet glycoprotein IIla; GSTM1, glutathione S-transferase mu 1; GSTP1, glutathione S-transferase pi 1; GSTT1, glutathione S-transferase theta 1; H19, imprinted maternally expressed transcript (non-protein coding); HLA-A, major histocompatibility complex, class I, $A$; HLA-B, major histocompatibility complex, class I, B; HLA-C, major histocompatibility complex, class I, C; HLA-E, major histocompatibility complex, class I, E; HLA-G, major histocompatibility complex, class I, G; HLA-DPB1, major histocompatibility complex, class II, DP beta 1; HLA-DQA1, major histocompatibility complex, class II, DQ alpha 1; HLA-DQB1, major histocompatibility complex, class II, DQ beta 1; HLA-DR', major histocompatibility complex, class II, DR loci; HO-1, heme oxygenase 1; IFNG, interferon, gamma; IGF-2, insulin-like growth factor 2; IL1B, interleukin 1, beta; IL1RN, interleukin 1 receptor antagonist; IL1R1, interleukin 1 receptor, type I; IL4, interleukin 4; IL6, interleukin 6; IL10, interleukin 10; IL12B, interleukin 12B; IL18, interleukin 18; IL21, interleukin 21; INDO, indole 2,3-dioxygenase; JAK2, Janus kinase 2; KDR, kinase insert domain receptor; KIR, killer cell immunoglobulin-like receptor; MBL, mannose binding lectin; MCP, membrane cofactor protein; MMP9, matrix metallopeptidase 9; MTHFD1, methylenetetrahydrofolate dehydrogenase 1; MTHFR, methylenetetrahydrofolate reductase; NAT2, N-acetyltransferase 2; NOS3, nitric oxide synthase 3; P53, p53 tumor suppressor; PAI-1, plasminogen activator inhibitor 1; PAPPA, pregnancy-associated plasma protein A; PGM1, phosphoglucomutase 1; PROGINS, progesterone receptor; PKR1, prokineticin receptor 1; PKR2, prokineticin receptor 1; PZ, protein Z; SELP, selectin P; STAT3, signal transducer and activator of transcription 3; SYCP3, synaptonemal complex protein 3; TAFI, thrombin-activatable fibrinolysis inhibitor; TGFB1, transforming growth factor, beta 1; TM, thrombomodulin; TNF $\alpha$, tumor necrosis factor-alpha; TNFB, tumor necrosis factor beta; TNFR1, tumor necrosis factor-alpha receptor 1; TSER, thymidylate synthetase enhancer region; TPH1, tryptophan hydroxylase 1; VEGF, vascular endothelial growth factor A; ZPI, protein Z-dependent protease inhibitor.

immune response related genes have been conducted for RM couples (Table 1). Unfortunately, most reports on the studied gene variants in relation to RM are controversial. There are numerous studies on polymorphisms affecting the expression of HLA-G (e.g., 14 bp indel in exon 8 of the $3^{\prime}$ UTR), the most dominant HLA antigen in blastocysts and trophoblastic tissue. Recent analyses have suggested that specific combinations of fetal (paternal) HLA-C and maternal killer immunoglobulin-like receptor (KIR) gene variants correlate with the risk to RM and other pregnancy complications (Hiby et al., 2010; Chazara et al., 2011; Colucci et al., 2011). KIRs regulate activity of uterine NK cells that are implicated in trophoblast invasion.

During the last years the focus has gradually switched from maternal factors to the genes involved in the function of placenta, carrying maternally and paternally originated gene copies (Table 1). The investigators have targeted placenta-specific genes such as hCG beta coding CGB5 and CGB8, as well as loci with wider expressional profile but exhibiting a specific role in placental function such as PAPPA, IGF-2, and $p 53$ (Suzuki et al., 2006; Ostojic et al., 2008; Tang et al., 2011). Although initial genetic studies have exhibited positive association between identified novel gene variants and an increased risk to RM, replication studies have to confirm these findings.

\section{ADVANCES AND FUTURE DIRECTIONS IN “OMICS” AND (EPI)GENETICS}

Genetic association studies based on pre-selected candidate genes have shown their limitations as RM represents a complex phenotype with no identified major genetic factor(s). In order to achieve the main goal - to identify predictive genetic risk factors and biomarkers for RM, advances are needed in clinic as well as in the research strategies. 


\section{RECRUITMENT STRATEGY}

Suggested advances in clinic include networking of research groups aiming to collect large sample-sets targeting RM phenotype under joint criteria and guidelines. Recruitment of both couples suffering from RM as well as controls should be encouraged, along with detailed clinical and reproductive history. Andrologists are to be involved to analyze reproductive parameters of male partners. Recruitment of duos (mother-placenta/fetus) or trios (mother-father-placenta/fetus) would provide further bonus. Studies should be enhanced by collecting the material for DNA, RNA, and protein studies from the same recruited family, e.g., parental blood samples, paternal sperm analysis, maternal endometrial tissue, multisite placental tissue sampling. A network of targeted clinics would facilitate carrying out validation of novel identified biomarkers by setting up the large multicentre studies.

\section{INTRODUCING “OMICS" INTO RM RESEARCH}

With rapidly evolving technological advances in genetics/“omics" there are multiple appealing perspectives in RM biomolecular research (Figure 1).

Up to now, no hypothesis-free genome-wide association studies (GWAS) for identification of common risk variants for RM have been performed. The main reason is that large number of uniformly defined RM affected individuals/couples is required to reach sufficient power in such heterogenous phenotype (Eichler et al., 2010). Copy number variations (CNVs) involving one or several loci are expected to exhibit a stronger effect on the phenotype compared to SNPs. Comparative genome hybridization-based microarray analysis of 26 euploidic miscarriages picked up 11 unique inherited CNVs, two of them involve genes TIMP2 $(86 \mathrm{~kb}$ duplication) and CTNNA3 (72 kb deletion) that are imprinted and maternally expressed in the placenta (Rajcan-Separovic et al., 2010). The first results of ongoing study using genome-wide genotyping data to map common CNVs demonstrated significantly more frequent prevalence of a 52.4-kb locus duplication on chromosome 5 among RM couples in Estonian and Danish population (Nagirnaja et al., 2011). These pilot studies alert for further investigations of rare and common CNVs as risk factors for RM.

Transcriptomics and proteomics based gene expression profiling in tissues responding to ongoing miscarriage event offers an attractive approach to identify differentially expressed biomarkers (Baek et al., 2007). A decreased expression level in chorionic villi from RM patients was shown for angiogenesis related loci, whereas the expression of several apoptosis-related genes was increased (Choi et al., 2003; Baek, 2004). The first whole-genome gene expression profiling of placental tissue from RM compared to uncomplicated pregnancies identified and replicated significant differential expression of TNF-related apoptosis-inducing ligand (TNFSF10; TRAIL) and S100A8 encoding for inflammatory marker calprotectin (heterodimer S100A8/A9; Rull et al., 2012). In comparative proteomics study applying 2-DE and MALDITOF/MS analyses of the follicular fluids of RM patients, abnormal expression of complement component $\mathrm{C} 3 \mathrm{c}$ chain $\mathrm{E}$, fibrinogen $\gamma$, antithrombin, angiotensinogen, and hemopexin precursor was reported (Kim et al., 2006b), and in the blood serum from RM patients the expression of ITI-H4 was altered (Kim et al., 2011).

\section{INTEGRATING OF GENETICS AND EPIGENETICS}

An important factor of placental development and function is epigenetic regulation governing the control of gene expression (Nelissen et al., 2011). Epigenomic marks include CpG methylation in DNA, histone modifications in chromatin, and non-coding regulatory RNAs. The specific features in placental epigenome are (i) active temporal dynamics - changes in epigenetic marks over course of pregnancy (Novakovic et al., 2011); (ii) complex organization of the DNA methylome and presence of tissue-specific differentially methylated regions (Choufani et al., 2011; Chu et al., 2011); (iii) abundance of parental-specific imprinted genes (Constancia et al., 2004; Moore and Oakey, 2011); (iv) evidence of polymorphic methylation or imprinting (Yuen et al., 2009); (v) placenta-specific microRNAs (miRNAs; Luo et al., 2009; Maccani and Marsit, 2009; Noguer-Dance et al., 2010); (vi) effect of environmental factors, e.g., maternal smoking (Maccani et al., 2010). Although altered placental epigenetics has been demonstrated in cases of fetal growth disturbances, preeclampsia, and gestational diabetes (Nelissen et al., 2011), there is limited information on the role of aberrant epigenetic profiling in RM. Epigenetic comparison of different cell types in early pregnancy is technically challenging. The only systematically addressed topic is skewed X-chromosome inactivation (XCI; the preferential inactivation of one of two Xchromosomes in female cells). Initial findings that XCI is increased in women with RM were promising (Sangha et al., 1999; Lanasa and Hogge, 2000; Van den Veyver, 2001), but the follow-up studies have revealed that the skewed XCI is associated rather with maternal age and fetal karyotype than solely with RM (Hogge et al., 2007; Pasquier et al., 2007; Warburton et al., 2009). Only single studies are available for gene-specific methylation in RM-related tissues (placenta, endometrium, maternal blood). For the biallelically expressed hCG beta-subunit coding CGB5, three placentas (including two RM) were reported with monoallelic expression of maternal alleles and hemimethylated gene promoters suggesting the association of methylation allelic polymorphism with pregnancy loss (Uuskula et al., 2011). Methyl transferase (G9aMT) and methylated histone (H3-K9) expressions were significantly lower in decidual/endometrial tissue of unexplained RM cases compared to controls (Fatima et al., 2011). As a support to the contribution of epigenetic regulation of implantation, significantly more abnormal methylation values for APC and imprinted PEG3 were reported in chorionic villus samples of abortions/stillbirth than in other studied genes (Zechner et al., 2009).

No targeted microRNA expression profiling has been performed for RM-related tissues. Still, there are placenta-specific miRNAs capable of crossing the placental barrier and detectable in maternal plasma (Chim et al., 2008; Miura et al., 2010) and an altered profile of several miRNAs has been shown in pregnancy complications. Among the RM-associated genes, the expression of HLA-G was shown to be modulated by a $3^{\prime}$ UTR polymorphism exhibiting allele-specific affinity to microRNAs miR-148a, miR-148b, and miR-152, and consequently differential mRNA degradation and translation suppression processes (Tan et al., 2007). A recent study showed association between two SNPs in pre-miR-125a and increased risk to RM (Hu et al., 2011). As miRNA expression data has been suggested to harbor potential in discriminating disease samples with high accuracy (Scholer et al., 
2011), there might be also strong perspectives in RM research and potential clinical implications.

In conclusion, future directions in investigating biomolecular risk factors for RM rely on integrating alternative approaches (DNA variants, gene and protein expression, epigenetic regulation) in studies of individual genes as well as whole-genome analysis. This would be greatly enhanced by extensive collaborative network between research centers and RM clinics.

\section{REFERENCES}

Al-Khateeb, G. M., Sater, M. S., Finan, R. R., Mustafa, F. E., Al-Busaidi, A. S., Al-Sulaiti, M. A., and Almawi, W. Y. (2011). Analysis of interleukin18 promoter polymorphisms and changes in interleukin-18 serum levels underscores the involvement of interleukin-18 in recurrent spontaneous miscarriage. Fertil. Steril. 96 , 921-926.

Alsheikh, F. S., Finan, R. R., Almawi, A. W., Mustafa, F. E., and Almawi, W. Y. (2012). Association of the R67X and W303X nonsense polymorphisms in the protein $\mathrm{Z}$-dependent protease inhibitor gene with idiopathic recurrent miscarriage. Mol. Hum. Reprod. $18,156-160$

Amani, D., Ravangard, F., Niikawa, N., Yoshiura, K., Karimzadeh, M., Dehaghani, A. S., and Ghaderi, A. (2011). Coding region polymorphisms in the indoleamine 2,3-dioxygenase (INDO) gene and recurrent spontaneous abortion. $J$. Reprod. Immunol. 88, 42-47.

Aruna, M., Nagaraja, T., Andal Bhaskar, S., Tarakeswari, S., Reddy, A. G., Thangaraj, K., Singh, L., and Reddy, B. M. (2011). Novel alleles of HLADQ and -DR loci show association with recurrent miscarriages among South Indian women. Hum. Reprod. 26, 765-774.

Aruna, M., Sudheer, P. S., Andal, S., Tarakeswari, S., Reddy, A. G., Thangaraj, K., Singh, L., and Reddy, B. M. (2010). HLA-G polymorphism patterns show lack of detectable association with recurrent spontaneous abortion. Tissue Antigens 76, 216-222.

Baek, K. H. (2004). Aberrant gene expression associated with recurrent pregnancy loss. Mol. Hum. Reprod. 10, 291-297.

Baek, K. H., Lee, E. J., and Kim, Y. S. (2007). Recurrent pregnancy loss: the key potential mechanisms. Trends Mol. Med. 13, 310-317.

Baxter, N., Sumiya, M., Cheng, S., Erlich, H., Regan, L., Simons, A., and Summerfield, J.A. (2001). Recurrent miscarriage and variant alleles of mannose binding lectin, tumour necrosis factor and lymphotoxin alpha genes. Clin. Exp. Immunol. 126, 529-534.

Berry, C. W., Brambati, B., Eskes, T. K., Exalto, N., Fox, H., Geraedts, J. P., Gerhard, I., Gonzales Gomes, F., Grudzinskas, J. G., and Hustin, J. (1995). The Euro-Team Early Pregnancy (ETEP) protocol for recurrent miscarriage. Hum. Reprod. 10, 1516-1520.

Beydoun, H., and Saftlas, A. F. (2005). Association of human leucocyte antigen sharing with recurrent spontaneous abortions. Tissue Antigens $65,123-135$.

Bianca, S., Barrano, B., Cutuli, N., Indaco, L., Cataliotti, A., Milana, G., Barone, C., and Ettore, G. (2010). No association between apolipoprotein E polymorphisms and recurrent pregnancy loss. Fertil. Steril. 93, 276.

Bogdanova, N., Horst, J., Chlystun, M., Croucher, P. J., Nebel, A., Bohring, A., Todorova, A., Schreiber, S., Gerke, V., Krawczak, M., and Markoff, A. (2007). A common haplotype of the annexin A5 (ANXA5) gene propregnancy loss. Hum. Mol. Genet. 16, 573-578.

Bolor, H., Mori, T., Nishiyama, S., Ito, Y., Hosoba, E., Inagaki, H., Kogo, H., Ohye, T., Tsutsumi, M., Kato, T., Tong, M., Nishizawa, H., PryorKoishi, K., Kitaoka, E., Sawada, T., Nishiyama, Y., Udagawa, Y., and Kurahashi, H. (2009). Mutations of the SYCP3 gene in women with recurrent pregnancy loss. Am. J. Hum. Genet. 84, 14-20.

Bombell, S., and McGuire, W. (2008). Cytokine polymorphisms in women with recurrent pregnancy loss: metaanalysis. Aust. N. Z. J. Obstet. Gynaecol. 48, 147-154.

Bottini, E., Coromaldi, L., Carapella, E., Pascone, R., Nicotra, M., Coghi, I., Lucarini, N., and Gloria-Bottini, F. (1983). Intrauterine death: an approach to the analysis of genetic heterogeneity. J. Med. Genet. 20, 196-198.

Brahem, S., Mehdi, M., Landolsi, H., Mougou, S., Elghezal, H., and Saad, A. (2011). Semen parameters and sperm DNA fragmentation as causes moter is associated with recurrent

\section{ACKNOWLEDGMENTS}

The studies on the genetics of recurrent miscarriages in the laboratory of Maris Laan have been supported by Wellcome Trust International Senior Research Fellowship (070191/Z/03/A) in Biomedical Science in Central Europe, HHMI International Scholarship Grant \#55005617, Estonian Science Foundation (grants \#7471, \#9030), and Estonian Ministry of Education and Science core grants SF0182721s06, SF0180022s12.

of recurrent pregnancy loss. Urology 78, 792-796.

Branch, D. W., Gibson, M., and Silver, R. M. (2010). Clinical practice. Recurrent miscarriage. N. Engl. J. Med. 363, 1740-1747.

Bricker, L., and Farquharson, R. G. (2002). Types of pregnancy loss in recurrent miscarriage: implications for research and clinical practice. Hum. Reprod. 17, 1345-1350.

Buchholz, T., Lohse, P., Kosian, E. and Thaler, C. J. (2004). Vasoconstrictively acting AT1R A1166C and NOS3 $4 / 5$ polymorphisms in recurrent spontaneous abortions (RSA). Am. J. Reprod. Immunol. 51, 323-328.

Buchholz, T., Lohse, P., Rogenhofer, N., Kosian, E., Pihusch, R., and Thaler C. J. (2003). Polymorphisms in the ACE and PAI-1 genes are associated with recurrent spontaneous miscarriages. Hum. Reprod. 18, 2473-2477.

Cecati, M., Giannubilo, S. R., Emanuelli, M., Tranquilli, A. L., and Saccucci, F. (2011). HLA-G and pregnancy adverse outcomes. Med. Hypotheses $76,782-784$.

Chazara, O., Xiong, S., and Moffett, A. (2011). Maternal KIR and fetal HLAC: a fine balance. J. Leukoc. Biol. 90, 703-716.

Chim, S. S., Shing, T. K., Hung, E. C. Leung, T. Y., Lau, T. K., Chiu, R. W., and Lo, Y. M. (2008). Detection and characterization of placental microRNAs in maternal plasma. Clin. Chem. 54, 482-490.

Choi, H. K., Choi, B. C., Lee, S. H., Kim, J. W., Cha, K. Y., and Baek, K. H. (2003). Expression of angiogenesis- and apoptosis-related genes in chorionic villi derived from recurrent pregnancy loss patients. Mol. Reprod. Dev. 66, 24-31.

Choi, Y. K., and Kwak-Kim, J. (2008). Cytokine gene polymorphisms in recurrent spontaneous abortions: a comprehensive review. Am. J. Reprod. Immunol. 60, 91-110.

Choufani, S., Shapiro, J. S., Susiarjo, M., Butcher, D. T., Grafodatskaya, D., Lou, Y., Ferreira, J. C., Pinto, D. Scherer, S. W., Shaffer, L. G., Coullin, P., Caniggia, I., Beyene, J., Slim,
R., Bartolomei, M. S., and Weksberg, R. (2011). A novel approach identifies new differentially methylated regions (DMRs) associated with imprinted genes. Genome Res. 21, 465-476.

Christiansen, O. B. (1996). A fresh look at the causes and treatments of recurrent miscarriage, especially its immunological aspects. Hum. Reprod. Update 2, 271-293.

Christiansen, O. B., Nybo Andersen, A. M., Bosch, E., Daya, S., Delves, P. J., Hviid, T. V., Kutteh, W. H., Laird S. M., Li, T. C., and van der Ven, K. (2005). Evidence-based investigations and treatments of recurrent pregnancy loss. Fertil. Steril. 83, 821-839.

Christiansen, O. B., Pedersen, B., Nielsen, H. S., and Nybo Andersen, A. M. (2004). Impact of the sex of first child on the prognosis in secondary recurrent miscarriage. Hum. Reprod. 19, 2946-2951.

Christiansen, O. B., Riisom, K., Lauritsen, J. G., Grunnet, N., and Jersild, C. (1989). Association of maternal HLA haplotypes with recurrent spontaneous abortions. Tissue Antigens 34, 190-199.

Christiansen, O. B., Ring, M., Rosgaard, A., Grunnet, N., and Gluud, C. (1999). Association between HLADR1 and -DR3 antigens and unexplained repeated miscarriage. Hum. Reprod. Update 5, 249-255.

Christiansen, O. B., Steffensen, R., Nielsen, H. S., and Varming, K. (2008). Multifactorial etiology of recurrent miscarriage and its scientific and clinical implications. Gynecol. Obstet. Invest. 66, 257-267.

Chu, T., Handley, D., Bunce, K., Surti, U., Hogge, W. A., and Peters, D. G. (2011). Structural and regulatory characterization of the placental epigenome at its maternal interface. PLoS ONE 6, e14723. doi:10.1371/journal.pone.0014723

Colucci, F., Boulenouar, S., Kieckbusch, J., and Moffett, A. (2011). How does variability of immune system genes affect placentation? Placenta 32, 539-545. 
Constancia, M., Kelsey, G., and Reik, W. (2004). Resourceful imprinting. Nature 432, 53-57.

Coulam, C. B., Jeyendran, R. S., Fishel, L. A., and Roussev, R. (2006a). Multiple thrombophilic gene mutations rather than specific gene mutations are risk factors for recurrent miscarriage. Am. J. Reprod. Immunol. 55, 360-368.

Coulam, C. B., Kay, C., and Jeyendran, R. S. (2006b). Role of p53 codon 72 polymorphism in recurrent pregnancy loss. Reprod. Biomed. Online 12, 378-382.

Crisan, T. O., Trifa, A., Farcas, M., Militaru, M., Netea, M., Pop, I., and Popp, R. (2011). The MTHFD1 c.1958 $\mathrm{G}>\mathrm{A}$ polymorphism and recurrent spontaneous abortions. J. Matern. Fetal Neonatal Med. 24, 189-192.

Cupisti, S., Fasching, P. A., Ekici, A. B., Strissel, P. L., Loehberg, C. R., Strick, R., Engel, J., Dittrich, R., Beckmann, M. W., and Goecke, T. W. (2009). Polymorphisms in estrogen metabolism and estrogen pathway genes and the risk of miscarriage. Arch. Gynecol. Obstet. 280, 395-400.

Dahabreh, I. J., Jones, A. V., Voulgarelis, M., Giannouli, S., Zoi, C., AlafakisTzannatos, C., Varla-Leftherioti, M., Moutsopoulos, H. M., Loukopoulos, D., Fotiou, S., Cross, N. C., and Zoi, K. (2009). No evidence for increased prevalence of JAK2 V617F in women with a history of recurrent miscarriage. Br. J. Haematol. 144, 802-803.

Daher, S., Shulzhenko, N., Morgun, A., Mattar, R., Rampim, G. F., Camano, L., and DeLima, M. G. (2003). Associations between cytokine gene polymorphisms and recurrent pregnancy loss. J. Reprod. Immunol. 58, 69-77.

Dendana, M., Hizem, S., Magddoud, K., Messaoudi, S., Zammiti, W., Nouira, M., Almawi, W. Y., and Mahjoub, T. (2011). Common polymorphisms in the P-selectin gene in women with recurrent spontaneous abortions. Gene. Available at: http://dx.doi.org/10.1016/j.gene. 2011.11.034

Dendana, M., Messaoudi, S., Hizem, S., Jazia, K. B., Almawi, W. Y., Gris, J. C., and Mahjoub, T. (2012). Endothelial protein $\mathrm{C}$ receptor $1651 \mathrm{C} / \mathrm{G}$ polymorphism and soluble endothelial protein $\mathrm{C}$ receptor levels in women with idiopathic recurrent miscarriage. Blood Coagul. Fibrinolysis 23, 30-34

Denschlag, D., Marculescu, R., Unfried, G., Hefler, L. A., Exner, M., Hashemi, A., Riener, E. K., Keck, C., Tempfer, C. B., and Wagner, O. (2004). The size of a microsatellite polymorphism of the haem oxygenase 1 gene is associated with idiopathic recurrent miscarriage. Mol. Hum. Reprod. 10, 211-214.

Dossenbach-Glaninger, A., van Trotsenburg, M., Helmer, H., Oberkanins, C., and Hopmeier, P. (2008). Association of the protein $\mathrm{Z}$ intron F G79A gene polymorphism with recurrent pregnancy loss. Fertil. Steril. 90, 1155-1160.

Dudding, T. E., and Attia, J. (2004). The association between adverse pregnancy outcomes and maternal factor V Leiden genotype: a meta-analysis. Thromb. Haemost. 91, 700-711.

Eichler, E. E., Flint, J., Gibson, G., Kong, A., Leal, S. M., Moore, J. H., and Nadeau, J. H. (2010). Missing heritability and strategies for finding the underlying causes of complex disease. Nat. Rev. Genet. 11, 446-450.

Faridi, R. M., and Agrawal, S. (2011). Killer immunoglobulin-like receptors (KIRs) and HLA-C allorecognition patterns implicative of dominant activation of natural killer cells contribute to recurrent miscarriages. Hum. Reprod. 26, 491-497.

Faridi, R. M., Das, V., Tripthi, G., Talwar, S., Parveen, F., and Agrawal, S. (2009). Influence of activating and inhibitory killer immunoglobulinlike receptors on predisposition to recurrent miscarriages. Hum. Reprod. 24, 1758-1764.

Fatima, N., Ahmed, S. H., Salhan, S., Rehman, S. M., Kaur, J., Owais, M., and Chauhan, S. S. (2011). Study of methyl transferase (G9aMT) and methylated histone (H3-K9) expressions in unexplained recurrent spontaneous abortion (URSA) and normal early pregnancy. Mol. Hum. Reprod. 17, 693-701.

Fatini, C., Gensini, F., Battaglini, B., Prisco, D., Cellai, A. P., Fedi, S., Marcucci, R., Brunelli, T., Mello, G., Parretti, E., Pepe, G., and Abbate, R. (2000). Angiotensin-converting enzyme DD genotype, angiotensin type 1 receptor CC genotype, and hyperhomocysteinemia increase first-trimester fetal-loss susceptibility. Blood Coagul. Fibrinolysis 11, 657-662.

Finan, R. R., Mustafa, F. E., Al-Zaman, I., Madan, S., Issa, A. A., and Almawi, W. Y. (2010). STAT3 polymorphisms linked with idiopathic recurrent miscarriages. Am. J. Reprod. Immunol. 63, 22-27.

Fowden, A. L., Sferruzzi-Perri, A. N., Coan, P. M., Constancia, M., and Burton, G. J. (2009). Placental efficiency and adaptation: endocrine regulation. J. Physiol. 587, 3459-3472.
Franssen, M. T., Musters, A. M., van der Veen, F., Repping, S., Leschot, N. J., Bossuyt, P. M., Goddijn, M., and Korevaar, J. C. (2011). Reproductive outcome after PGD in couples with recurrent miscarriage carrying a structural chromosome abnormality: a systematic review. Hum. Reprod. Update 17, 467-475.

Galazios, G., Papazoglou, D., Zografou, C., Maltezos, E., and Liberis, V. (2011). Alpha2B-adrenergic receptor insertion/deletion polymorphism in women with spontaneous recurrent abortions. J. Obstet. Gynaecol. Res. 37, 108-111.

Gerhardt, A., Scharf, R. E., MikatDrozdzynski, B., Krussel, J. S., Bender, H. G., and Zotz, R. B. (2005). The polymorphism of platelet membrane integrin alpha2betal (alpha2807TT) is associated with premature onset of fetal loss. Thromb. Haemost. 93, 124-129.

Gloria-Bottini, F., Nicotra, M., Lucarini, N., Borgiani, P., La Torre, M., Amante, A., Gimelfarb, A., and Bottini, E. (1996). Phosphotyrosineprotein-phosphatases and human reproduction: an association between low molecular weight acid phosphatase (ACP1) and spontaneous abortion. Dis. Markers 12, 261-269.

Goodman, C., Goodman, C. S., Hur, J., Jeyendran, R. S., and Coulam, C. (2009a). The association of Apoprotein $\mathrm{E}$ polymorphisms with recurrent pregnancy loss. Am. J. Reprod. Immunol. 61, 34-38.

Goodman, C., Hur, J., Goodman, C. S., Jeyendran, R. S., and Coulam, C. (2009b). Are polymorphisms in the ACE and PAI-1 genes associated with recurrent spontaneous miscarriages? Am. J. Reprod. Immunol. 62, 365-370.

Goodman, C. S., Coulam, C. B., Jeyendran, R. S., Acosta, V. A., and Roussev, R. (2006). Which thrombophilic gene mutations are risk factors for recurrent pregnancy loss? Am. J. Reprod. Immunol. 56, 230-236.

Hanna, C. W., Blair, J. D., Stephenson, M. D., and Robinson, W. P. (2011). Absence of SYCP3 mutations in women with recurrent miscarriage with at least one trisomic miscarriage. Reprod. Biomed. Online. Available at: http://dx. doi.org/10.1016/j.rbmo.2011.10.013

Hefler, L. A., Tempfer, C. B., Bashford, M. T., Unfried, G., Zeillinger, R. Schneeberger, C., Koelbl, H., Nagele, F., and Huber, J. C. (2002). Polymorphisms of the angiotensinogen gene, the endothelial nitric oxide synthase gene, and the interleukin-1beta gene promoter in women with idiopathic recurrent miscarriage. Mol. Hum. Reprod. 8, 95-100.

Heuser, C. C., Eller, A. G., Warren, J., Branch, D. W., Salmon, J., and Silver, R. M. (2011). A case-control study of membrane cofactor protein mutations in two populations of patients with early pregnancy loss. J. Reprod. Immunol. 91, 71-75.

Hiby, S. E., Apps, R., Sharkey, A. M., Farrell, L. E., Gardner, L., Mulder, A., Claas, F. H., Walker, J. J., Redman, C. W., Morgan, L., Tower, C., Regan, L., Moore, G. E., Carrington, M., and Moffett, A. (2010). Maternal activating KIRs protect against human reproductive failure mediated by fetal HLA-C2. J. Clin. Invest. 120, 4102-4110.

Hiby, S. E., Regan, L., Lo, W., Farrell, L., Carrington, M., and Moffett, A. (2008). Association of maternal killer-cell immunoglobulin-like receptors and parental HLA-C genotypes with recurrent miscarriage. Hum. Reprod. 23, 972-976.

Hirvonen, A., Taylor, J. A., Wilcox, A., Berkowitz, G., Schachter, B., Chaparro, C., and Bell, D. A. (1996). Xenobiotic metabolism genes and the risk of recurrent spontaneous abortion. Epidemiology 7, 206-208.

Hogge, W. A., Prosen, T. L., Lanasa, M. C., Huber, H. A., and Reeves, M. F. (2007). Recurrent spontaneous abortion and skewed $\mathrm{X}$-inactivation: is there an association? Am. J. Obstet. Gynecol. 196, e381-386; discussion e386-e388.

Hohlagschwandtner, M., Unfried, G., Heinze, G., Huber, J. C., Nagele, F., and Tempfer, C. (2003). Combined thrombophilic polymorphisms in women with idiopathic recurrent miscarriage. Fertil. Steril. 79, 1141-1148.

Hu, Y., Liu, C. M., Qi, L., He, T. Z., ShiGuo, L., Hao, C. J., Cui, Y., Zhang, N., Xia, H. F., and Ma, X. (2011). Two common SNPs in pri-miR-125a alter the mature miRNA expression and associate with recurrent pregnancy loss in a Han-Chinese population. RNA Biol. 8, 861-872.

Hviid, T. V., Hylenius, S., Lindhard, A., and Christiansen, O. B. (2004). Association between human leukocyte antigen-G genotype and success of in vitro fertilization and pregnancy outcome. Tissue Antigens 64, 66-69.

Iinuma, Y., Sugiura-Ogasawara, M., Makino, A., Ozaki, Y., Suzumori, N., and Suzumori, K. (2002). Coagulation factor XII activity, but not an associated common genetic polymorphism $(46 \mathrm{C} / \mathrm{T})$, is linked to 
recurrent miscarriage. Fertil. Steril. 77, 353-356.

Ivanov, P. D., Komsa-Penkova, R. S., Konova, E. I., Tsvyatkovska, T. M., Kovacheva, K. S., Simeonova, M. N., and Tanchev, S. Y. (2010). Polymorphism A1/A2 in the cell surface integrin subunit beta 3 and disturbance of implantation and placentation in women with recurrent pregnancy loss. Fertil. Steril. 94, 2843-2845.

Jauniaux, E., Farquharson, R. G., Christiansen, O. B., and Exalto, N. (2006). Evidence-based guidelines for the investigation and medical treatment of recurrent miscarriage. Hum. Reprod. 21, 2216-2222.

Jivraj, S., Rai, R., Underwood, J., and Regan, L. (2006). Genetic thrombophilic mutations among couples with recurrent miscarriage. Hum. Reprod. 21, 1161-1165.

Kaare, M., Butzow, R., Ulander, V. M., Kaaja, R., Aittomaki, K., and Painter, J. N. (2009a). Study of p53 gene mutations and placental expression in recurrent miscarriage cases. Reprod. Biomed. Online 18, 430-435.

Kaare, M., Gotz, A., Ulander, V. M., Ariansen, S., Kaaja, R., Suomalainen, A., and Aittomaki, K. (2009b). Do mitochondrial mutations cause recurrent miscarriage? Mol. Hum. Reprod. 15, 295-300.

Kaare, M., Ulander, V. M., Painter, J. N., Ahvenainen, T., Kaaja, R., and Aittomaki, K. (2007). Variations in the thrombomodulin and endothelial protein $\mathrm{C}$ receptor genes in couples with recurrent miscarriage. Hum. Reprod. 22, 864-868.

Kamali-Sarvestani, E., Zolghadri, J., Gharesi-Fard, B., and Sarvari, J. (2005). Cytokine gene polymorphisms and susceptibility to recurrent pregnancy loss in Iranian women. J. Reprod. Immunol. 65, 171-178.

Kanai, T., Fujii, T., Keicho, N., Tokunaga, K., Yamashita, T., Hyodo, H., Miki, A., Unno, N., Kozuma, S., and Taketani, Y. (2001). Polymorphism of human leukocyte antigen-E gene in the Japanese population with or without recurrent abortion. Am. J. Reprod. Immunol. 45, 168-173.

Karhukorpi, J., Laitinen, T., and Karttunen, R. (2003). Searching for links between endotoxin exposure and pregnancy loss: CD14 polymorphism in idiopathic recurrent miscarriage. Am. J. Reprod. Immunol. 5, 346-350.

Karvela, M., Papadopoulou, S., Tsaliki, E., Konstantakou, E., Hatzaki, A., Florentin-Arar, L., and Lamnissou, K. (2008a). Endothelial nitric oxide synthase gene polymorphisms in recurrent spontaneous abortions. Arch. Gynecol. Obstet. 278, 349-352.

Karvela, M., Stefanakis, N., Papadopoulou, S., Tsitilou, S. G., Tsilivakos, V., and Lamnissou, K. (2008b). Evidence for association of the G1733A polymorphism of the androgen receptor gene with recurrent spontaneous abortions. Fertil. Steril. 90, e9-e12.

Kim, M. S., Gu, B. H., Song, S., Choi, B. C., Cha, D. H., and Baek, K. H. (2011). ITI-H4, as a biomarker in the serum of recurrent pregnancy loss (RPL) patients. Mol. Biosyst. 7, 1430-1440.

Kim, N. K., Choi, Y. K., Kang, M. S., Choi, D. H., Cha, S. H., An, M. O., Lee, S., Jeung, M., Ko, J. J., and Oh, D. (2006a). Influence of combined methylenetetrahydrofolate reductase (MTHFR) and thymidylate synthase enhancer region (TSER) polymorphisms to plasma homocysteine levels in Korean patients with recurrent spontaneous abortion. Thromb. Res. 117, 653-658.

Kim, Y. S., Kim, M. S., Lee, S. H., Choi, B. C., Lim, J. M., Cha, K. Y., and Baek, K. H. (2006b). Proteomic analysis of recurrent spontaneous abortion: identification of an inadequately expressed set of proteins in human follicular fluid. Proteomics 6, 3445-3454.

Kolte, A. M., Nielsen, H. S., Moltke, I., Degn, B., Pedersen, B., Sunde, L., Nielsen, F. C., and Christiansen, O. B. (2011). A genome-wide scan in affected sibling pairs with idiopathic recurrent miscarriage suggests genetic linkage. Mol. Hum. Reprod. 17, 379-385.

Kolte, A. M., Steffensen, R., Nielsen, H. S., Hviid, T. V., and Christiansen, O. B. (2010). Study of the structure and impact of human leukocyte antigen (HLA)-G-A, HLA-G$\mathrm{B}$, and HLA-G-DRB1 haplotypes in families with recurrent miscarriage. Hum. Immunol. 71, 482-488.

Kovalevsky, G., Gracia, C. R., Berlin, J. A., Sammel, M. D., and Barnhart, K. T. (2004). Evaluation of the association between hereditary thrombophilias and recurrent pregnancy loss: a meta-analysis. Arch. Intern. Med. 164, 558-563.

Kruse, C., Steffensen, R., Varming, K., and Christiansen, O. B. (2004). A study of HLA-DR and -DQ alleles in 588 patients and 562 controls confirms that HLA-DRB1*03 is associated with recurrent miscarriage. Hum. Reprod. 19, 1215-1221.
Lanasa, M. C., and Hogge, W. A. (2000). $\mathrm{X}$ chromosome defects as an etiology of recurrent spontaneous abortion. Semin. Reprod. Med. 18, 97-103.

Lewis, R. M., Cleal, J. K., and Hanson, M. A. (2012). Review: placenta, evolution and lifelong health. Placenta 33, S28-S32.

Litridis, I., Kapnoulas, N., Natisvili, T., Agiannitopoulos, K., Peraki, O., Ntostis, P., Pantos, K., and Lamnissou, K. (2011). Genetic variation in the CYP17 gene and recurrent spontaneous abortions. Arch. Gynecol. Obstet. 283, 289-293.

Luo, S. S., Ishibashi, O., Ishikawa, G., Ishikawa, T., Katayama, A. Mishima, T., Takizawa, T., Shigihara, T., Goto, T., Izumi, A., Ohkuchi, A., Matsubara, S., and Takeshita, T. (2009). Human villous trophoblasts express and secrete placenta-specific microRNAs into maternal circulation via exosomes. Biol. Reprod. 81 717-729.

Maccani, M. A., Avissar-Whiting, M., Banister, C. E., McGonnigal, B., Padbury, J. F., and Marsit, C. J. (2010). Maternal cigarette smoking during pregnancy is associated with downregulation of miR-16, miR-21, and miR-146a in the placenta. Epigenetics 5, 583-589.

Maccani, M. A., and Marsit, C. J. (2009). Epigenetics in the placenta. Am. J. Reprod. Immunol. 62, 78-89.

Mannik, J., Vaas, P., Rull, K., Teesalu, P., Rebane, T., and Laan, M. (2010). Differential expression profile of growth hormone/chorionic somatomammotropin genes in placenta of small- and large-forgestational-age newborns. J. Clin. Endocrinol. Metab. 95, 2433-2442.

Masini, S., Ticconi, C., Gravina, P., Tomassini, M., Pietropolli, A., Forte, V., Federici, G., Piccione, E., and Bernardini, S. (2009). Thrombinactivatable fibrinolysis inhibitor polymorphisms and recurrent pregnancy loss. Fertil. Steril. 92, 694-702.

McLachlan, R. I., and O'Bryan, M. K. (2010). Clinical review: state of the art for genetic testing of infertile men. J. Clin. Endocrinol. Metab. 95, 1013-1024.

Menasha, J., Levy, B., Hirschhorn, K. and Kardon, N. B. (2005). Incidence and spectrum of chromosome abnormalities in spontaneous abortions: new insights from a 12 -year study. Genet. Med. 7, 251-263.

Messaoudi, S., Al-Khateeb, G. M., Dendana, M., Sater, M. S., Jazia, K. B., Nouira, M., Almawi, W. Y., and Mahjoub, T. (2011). Genetic variations in the interleukin-21 gene and the risk of recurrent idiopathic spontaneous miscarriage. Eur. Cytokine Netw. 22, 123-126.

Miura, K., Miura, S., Yamasaki, K., Higashijima, A., Kinoshita, A., Yoshiura, K., and Masuzaki, H. (2010). Identification of pregnancyassociated microRNAs in maternal plasma. Clin. Chem. 56, 1767-1771.

Miyamura, H., Nishizawa, H., Ota, S., Suzuki, M., Inagaki, A., Egusa, H., Nishiyama, S., Kato, T., Pryor-Koishi, K., Nakanishi, I., Fujita, T., Imayoshi, Y., Markoff, A., Yanagihara, I., Udagawa, Y., and Kurahashi, H. (2011). Polymorphisms in the annexin A5 gene promoter in Japanese women with recurrent pregnancy loss. Mol. Hum. Reprod. 17, 447-452.

Mizutani, E., Suzumori, N., Ozaki, Y., Oseto, K., Yamada-Namikawa, C., Nakanishi, M., and SugiuraOgasawara, M. (2011). SYCP3 mutation may not be associated with recurrent miscarriage caused by aneuploidy. Hum. Reprod. 26, 1259-1266.

Moghraby, J. S., Tamim, H., Anacan, V., Al Khalaf, H., and Moghraby, S. A. (2010). HLA sharing among couples appears unrelated to idiopathic recurrent fetal loss in Saudi Arabia. Hum. Reprod. 25, 1900-1905.

Moore, G. E., and Oakey, R. (2011). The role of imprinted genes in humans. Genome Biol. 12, 106.

Mosaad, Y. M., Abdel-Dayem, Y., ElDeek, B. S., and El-Sherbini, S. M. (2011). Association between HLA-E *0101 homozygosity and recurrent miscarriage in Egyptian women. Scand. J. Immunol. 74, 205-209.

Musters, A. M., Taminiau-Bloem, E. F., van den Boogaard, E., van der Veen, F., and Goddijn, M. (2011). Supportive care for women with unexplained recurrent miscarriage: patients' perspectives. Hum. Reprod. 26, 873-877.

Naeimi, S., Ghiam, A. F., Mojtahedi, Z., Dehaghani, A. S., Amani, D., and Ghaderi, A. (2006). Interleukin18 gene promoter polymorphisms and recurrent spontaneous abortion. Eur. J. Obstet. Gynecol. Reprod. Biol. 128, 5-9.

Nagirnaja, L., Kasak, L., Palta, P., Rull, K., Christiansen, O. B., Esko, T., Remm, M., Metspalu, A., and Laan, M. (2011). Role of DNA copy number variations in genetic predisposition to recurrent pregnancy loss. J. Reprod. Immunol. 90, 145.

Nagirnaja, L., Rull, K., Uuskula, L., Hallast, P., Grigorova, M., and Laan, M. (2010). Genomics and genetics of gonadotropin beta-subunit 
genes: unique FSHB and duplicated LHB/CGB loci. Mol. Cell. Endocrinol. 329, 4-16.

Nelen, W. L., Blom, H. J., Steegers, E. A., den Heijer, M., and Eskes, T. K. (2000). Hyperhomocysteinemia and recurrent early pregnancy loss: a meta-analysis. Fertil. Steril. 74, 1196-1199.

Nelissen, E. C., van Montfoort, A. P., Dumoulin, J. C., and Evers, J. L. (2011). Epigenetics and the placenta. Hum. Reprod. Update 17, 397-417.

Newbern, D., and Freemark, M. (2011). Placental hormones and the control of maternal metabolism and fetal growth. Curr. Opin. Endocrinol. Diabetes Obes. 18, 409-416.

Nicotra, M., Bottini, N., Grasso, M., Gimelfarb, A., Lucarini, N., Cosmi, E., and Bottini, E. (1998). Adenosine deaminase and human reproduction: a comparative study of fertile women and women with recurrent spontaneous abortion. Am. J. Reprod. Immunol. 39, 266-270.

Nicotra, M., Lucarini, N., Battista, C., Discepoli, L., Coghi, I. M., and Bottini, E. (1982). Genetic polymorphisms and human reproduction: a study of phosphoglucomutase in spontaneous abortion. Int. J. Fertil. 27, 229-233.

Nielsen, H. S. (2011). Secondary recurrent miscarriage and $\mathrm{H}-\mathrm{Y}$ immunity. Hum. Reprod. Update 17, 558-574.

Noguer-Dance, M., Abu-Amero, S., AlKhtib, M., Lefevre, A., Coullin, P., Moore, G. E., and Cavaille, J. (2010). The primate-specific microRNA gene cluster (C19MC) is imprinted in the placenta. Hum. Mol. Genet. 19, 3566-3582.

Novakovic, B., Yuen, R. K., Gordon, L., Penaherrera, M. S., Sharkey, A., Moffett, A., Craig, J. M., Robinson, W. P., and Saffery, R. (2011). Evidence for widespread changes in promoter methylation profile in human placenta in response to increasing gestational age and environmental/stochastic factors. BMC Genomics 12, 529. doi:10.1186/1471-2164-12-529

Nybo Andersen, A. M., Wohlfahrt, J., Christens, P., Olsen, J., and Melbye, M. (2000). Maternal age and fetal loss: population based register linkage study. BMJ 320, 1708-1712.

Ober, C., Aldrich, C. L., Chervoneva, I., Billstrand, C., Rahimov, F., Gray, H. L., and Hyslop, T. (2003). Variation in the HLA-G promoter region influences miscarriage rates. Am. J. Hum. Genet. 72, 1425-1435.

Ogasawara, M., Aoki, K., Okada, S., and Suzumori, K. (2000). Embryonic karyotype of abortuses in relation to the number of previous miscarriages. Fertil. Steril. 73, 300-304.

Ostojic, S., Pereza, N., Volk, M., Kapovic, M., and Peterlin, B. (2008). Genetic predisposition to idiopathic recurrent spontaneous abortion: contribution of genetic variations in IGF2 and H19 imprinted genes. Am. J. Reprod. Immunol. 60, 111-117.

Ostojic, S., Volk, M., Medica, I., Kapovic, M., Meden-Vrtovec, H., and Peterlin, B. (2007). Polymorphisms in the interleukin-12/18 genes and recurrent spontaneous abortion. Am. J. Reprod. Immunol. 58, 403-408.

Papazoglou, D., Galazios, G., Papatheodorou, K., Liberis, V., Papanas, N., Maltezos, E., and Maroulis, G. B. (2005). Vascular endothelial growth factor gene polymorphisms and idiopathic recurrent pregnancy loss. Fertil. Steril. 83, 959-963.

Parveen, F., Faridi, R. M., Alam, S., and Agrawal, S. (2011a). Genetic analysis of eNOS gene polymorphisms in association with recurrent miscarriage among North Indian women. Reprod. Biomed. Online 23, 124-131.

Parveen, F., Faridi, R. M., Singh, B., and Agrawal, S. (2011b). Analysis of CCR5 and CX3CR1 gene polymorphisms in association with unexplained recurrent miscarriages among north Indian women. Cytokine 56, 239-244.

Parveen, F., Faridi, R. M., Das, V., Tripathi, G., and Agrawal, S. (2010). Genetic association of phase I and phase II detoxification genes with recurrent miscarriages among North Indian women. Mol. Hum. Reprod. 16, 207-214.

Parveen, F., Tripathi, G., Singh, B., and Agrawal, S. (2009a). Association of chemokines receptor (CCR5 Delta32) in idiopathic recurrent miscarriages among north Indians. Arch. Gynecol. Obstet. 280, 229-234.

Parveen, F., Tripathi, G., Singh, B., Faridi, R. M., and Agrawal, S. (2009b). Acetylcholinesterase gene polymorphism and recurrent pregnancy loss. Int. J. Gynaecol. Obstet. 106, 68-69.

Pasquier, E., Bohec, C., De Saint Martin, L., Le Marechal, C., Le Martelot, M. T., Roche, S., Laurent, Y., Ferec, C., Collet, M., and Mottier, D. (2007). Strong evidence that skewed $\mathrm{X}$-chromosome inactivation is not associated with recurrent pregnancy loss: an incident paired case control study. Hum. Reprod. 22, 2829-2833.

Philipp, T., Philipp, K., Reiner, A., Beer, F., and Kalousek, D. K. (2003). Embryoscopic and cytogenetic analysis of 233 missed abortions: factors involved in the pathogenesis of developmental defects of early failed pregnancies. Hum. Reprod. $18,1724-1732$.

Pietrowski, D., Bettendorf, H., Riener, E. K., Keck, C., Hefler, L. A., Huber, J. C., and Tempfer, C. (2005). Recurrent pregnancy failure is associated with a polymorphism in the p53 tumour suppressor gene. Hum. Reprod. 20, 848-851.

Pietrowski, D., Tempfer, C., Bettendorf, H., Burkle, B., Nagele, F., Unfried, G., and Keck, C. (2003). Angiopoietin-2 polymorphism in women with idiopathic recurrent miscarriage. Fertil. Steril. 80, 1026-1029.

Pihusch, R., Buchholz, T., Lohse, P., Rubsamen, H., Rogenhofer, N., Hasbargen, U., Hiller, E., and Thaler, C. J. (2001). Thrombophilic gene mutations and recurrent spontaneous abortion: prothrombin mutation increases the risk in the first trimester. Am. J. Reprod. Immunol. 46, 124-131.

Prigoshin, N., Tambutti, M., Larriba, J., Gogorza, S., and Testa, R. (2004). Cytokine gene polymorphisms in recurrent pregnancy loss of unknown cause. Am. J. Reprod. Immunol. 52, 36-41.

Rai, R., and Regan, L. (2006). Recurrent miscarriage. Lancet 368, 601-611.

Rajcan-Separovic, E., Diego-Alvarez, D., Robinson, W. P., Tyson, C., Qiao, Y., Harvard, C., Fawcett, C., Kalousek, D., Philipp, T., Somerville, M. J., and Stephenson, M. D. (2010). Identification of copy number variants in miscarriages from couples with idiopathic recurrent pregnancy loss. Hum. Reprod. 25, 2913-2922.

Ren, A., and Wang, J. (2006). Methylenetetrahydrofolate reductase C677T polymorphism and the risk of unexplained recurrent pregnancy loss: a meta-analysis. Fertil. Steril. 86, 1716-1722.

Rey, E., Kahn, S. R., David, M., and Shrier, I. (2003). Thrombophilic disorders and fetal loss: a meta-analysis. Lancet 361, 901-908.

Risch, N., and Merikangas, K. (1996). The future of genetic studies of complex human diseases. Science 273, 1516-1517.

Rodger, M. A., Betancourt, M. T., Clark, P., Lindqvist, P. G., Dizon-Townson, D., Said, J., Seligsohn, U., Carrier, M., Salomon, O., and Greer, I. A. (2010). The association of factor $\mathrm{V}$ Leiden and prothrombin gene mutation and placenta-mediated pregnancy complications: a systematic review and meta-analysis of prospective cohort studies. PLoS
Med. 7, e1000292. doi:10.1371/journal.pmed.1000292

Rull, K., Nagirnaja, L., Ulander, V. M., Kelgo, P., Margus, T., Kaare, M., Aittomaki, K., and Laan, M. (2008). Chorionic gonadotropin beta-gene variants are associated with recurrent miscarriage in two European populations. J. Clin. Endocrinol. Metab. 93, 4697-4706.

Rull, K., Tomberg, K., Kõks, S., Männik, J., Möls, M., Sirotkina, M. Värv, S., and Laan, M. (2012). TNF-related apoptosis-inducing ligand TRAIL as a potential biomarker for early pregnancy complications. J. Clin. Endocrinol. Metab. 97. doi: 10.1210/jc.2011-3192

Saijo, Y., Sata, F., Yamada, H., Konodo, T., Kato, E. H., Kataoka, S., Shimada, S., Morikawa, M., Minakami, H., and Kishi, R. (2004a). Interleukin-4 gene polymorphism is not involved in the risk of recurrent pregnancy loss. Am. J. Reprod. Immunol. 52, 143-146.

Saijo, Y., Sata, F., Yamada, H., Suzuki, K., Sasaki, S., Kondo, T., Gong, Y. Y., Kato, E. H., Shimada, S., Morikawa, M., Minakami, H., and Kishi, R. (2004b). Ah receptor, CYP1A1, CYP1A2 and CYP1B1 gene polymorphisms are not involved in the risk of recurrent pregnancy loss. Mol. Hum. Reprod. 10, 729-733

Salker,M., Teklenburg,G., Molokhia,M., Lavery, S., Trew, G., Aojanepong, T., Mardon, H. J., Lokugamage, A. U., Rai, R., Landles, C., Roelen, B. A., Quenby, S., Kuijk, E. W., Kavelaars, A., Heijnen, C. J., Regan, L., Macklon, N. S., and Brosens, J. J. (2010). Natural selection of human embryos: impaired decidualization of endometrium disables embryo-maternal interactions and causes recurrent pregnancy loss. PLoS ONE 5, e10287. doi:10.1371/journal.pone.0010287

Sangha, K. K., Stephenson, M. D., Brown, C. J., and Robinson, W. P. (1999). Extremely skewed $\mathrm{X}$-chromosome inactivation is increased in women with recurrent spontaneous abortion. Am. J. Hum. Genet. 65, 913-917.

Sata, F., Yamada, H., Kondo, T., Gong, Y., Tozaki, S., Kobashi, G., Kato, E. H., Fujimoto, S., and Kishi, R. (2003a). Glutathione S-transferase M1 and $\mathrm{T} 1$ polymorphisms and the risk of recurrent pregnancy loss. Mol. Hum. Reprod. 9, 165-169.

Sata, F., Yamada, H., Yamada, A., Kato, E. H., Kataoka, S., Saijo, Y., Kondo, T., Tamaki, J., Minakami, H., and Kishi, R. (2003b). A polymorphism in the CYP17 gene relates to the risk of recurrent pregnancy loss. Mol. Hum. Reprod. 9, 725-728. 
Sata, F., Yamada, H., Suzuki, K., Saijo, Y., Kato, E. H., Morikawa, M., Minakami, H., and Kishi, R. (2005). Caffeine intake, CYP1A2 polymorphism and the risk of recurrent pregnancy loss. Mol. Hum. Reprod. 11, 357-360.

Scholer, N., Langer, C., and Kuchenbauer, F. (2011). Circulating microRNAs as biomarkers - true blood? Genome Med 3, 72.

Seyedhassani, S. M., Houshmand, M., Kalantar, S. M., Modabber, G., and Aflatoonian, A. (2010). No mitochondrial DNA deletions but more D-loop point mutations in repeated pregnancy loss. J. Assist. Reprod. Genet. 27, 641-648.

Silver, R. M., Zhao, Y., Spong, C. Y., Sibai, B., Wendel, G. Jr., Wenstrom, K., Samuels, P., Caritis, S. N., Sorokin, Y., Miodovnik, M., O'Sullivan, M. J., Conway, D., and Wapner, R. J. (2010). Prothrombin gene G20210A mutation and obstetric complications. Obstet. Gynecol. 115, 14-20.

Singh, K., Nair, R. R., and Khanna, A. (2012). Functional SNP -1562C/T in the promoter region of MMP9 and recurrent early pregnancy loss. Reprod. Biomed. Online 24, 61-65.

Sotiriadis, A., Makrigiannakis, A., Stefos, T., Paraskevaidis, E., and Kalantaridou, S. N. (2007). Fibrinolytic defects and recurrent miscarriage: a systematic review and meta-analysis. Obstet. Gynecol. 109, 1146-1155.

Steck, T., van der Ven, K., Kwak, J., Beer, A., and Ober, C. (1995). HLADQA1 and HLA-DQB1 haplotypes in aborted fetuses and couples with recurrent spontaneous abortion. J. Reprod. Immunol. 29, 95-104.

Steffensen, R., Christiansen, O. B., Bennett, E. P., and Jersild, C. (1998). HLA-E polymorphism in patients with recurrent spontaneous abortion. Tissue Antigens 52, 569-572.

Stephenson, M. D., and Sierra, S. (2006). Reproductive outcomes in recurrent pregnancy loss associated with a parental carrier of a structural chromosome rearrangement. Hum. Reprod. 21, 1076-1082.

Su, M. T., Lin, S. H., and Chen, Y. C. (2011a). Association of sex hormone receptor gene polymorphisms with recurrent pregnancy loss: a systematic review and meta-analysis. Fertil. Steril. 96, 1435-1444.

Su, M. T., Lin, S. H., Lee, I. W., Chen, Y. C., and Kuo, P. L. (2011b). Association of polymorphisms/haplotypes of the genes encoding vascular endothelial growth factor and its KDR receptor with recurrent pregnancy loss. Hum. Reprod. 26, 758-764.
Su, M. T., Lin, S. H., Lee, I. W., Chen, Y. C., Hsu, C. C., Pan, H. A., and Kuo, P. L. (2010). Polymorphisms of endocrine gland-derived vascular endothelial growth factor gene and its receptor genes are associated with recurrent pregnancy loss. Hum. Reprod. 25, 2923-2930.

Sullivan, A. E., Nelson, L., Frias, A. E., Porter, T. F., Branch, D. W., and Silver, R. M. (2006). The aryl hydrocarbon receptor nuclear translocator gene polymorphism in patients with recurrent miscarriage. Am. J. Reprod. Immunol. 55, 51-53.

Suryanarayana, V., Deenadayal, M., and Singh, L. (2004). Association of CYP1A1 gene polymorphism with recurrent pregnancy loss in the South Indian population. Hum. Reprod. 19, 2648-2652.

Suryanaryana, V. V., Rao, L., Kanakavalli, M. K., Padmalatha, V. V., Deenadayal, M., and Singh, L. (2007). Role of CYP17 and CYP19 polymorphisms in idiopathic recurrent miscarriages among South Indian women. Reprod. Biomed. Online 14, 341-347.

Suzuki, K., Sata, F., Yamada, H., Saijo, Y., Tsuruga, N., Minakami, H., and Kishi, R. (2006). Pregnancyassociated plasma protein-A polymorphism and the risk of recurrent pregnancy loss. J. Reprod. Immunol. 70, 99-108.

Takakuwa, K., Hataya, I., Arakawa, M., Kikuchi, A., Higashino, M., Yasuda, M., Kurabayashi, T., and Tanaka, K. (1999). Possible susceptibility of the HLA-DPB1*0402 and HLA-DPB $1 * 04$ alleles to unexplained recurrent abortion: analysis by means of polymerase chain reaction-restricted fragment length polymorphism method. Am. J. Reprod. Immunol. 42, 233-239.

Tan, Z., Randall, G., Fan, J., CamorettiMercado, B., Brockman-Schneider, R., Pan, L., Solway, J., Gern, J. E., Lemanske, R. F., Nicolae, D., and Ober, C. (2007). Allele-specific targeting of microRNAs to HLA-G and risk of asthma. Am. J. Hum. Genet. 81, 829-834.

Tang, A. W., and Quenby, S. (2010). Recent thoughts on management and prevention of recurrent early pregnancy loss. Curr. Opin. Obstet. Gynecol. 22, 446-451.

Tang, W., Zhou, X., Chan, Y., Wu, X., and Luo, Y. (2011). p53 codon 72 polymorphism and recurrent pregnancy loss: a meta-analysis. J. Assist. Reprod. Genet. 28, 965-969.

Topalidou, M., Effraimidou, S., Farmakiotis, D., Papadakis, E., Papaioannou, G., Korantzis, I., and Garipidou, V. (2009). Low protein $\mathrm{Z}$ levels, but not the intron $\mathrm{F}$ G79A polymorphism, are associated with unexplained pregnancy loss. Thromb. Res. 124, 24-27.

Toth, B., Vocke, F., Rogenhofer, N., Friese, K., Thaler, C. J., and Lohse, P. (2008). Paternal thrombophilic gene mutations are not associated with recurrent miscarriage. Am. J. Reprod. Immunol. 60, 325-332.

Traina, E., Daher, S., Moron, A. F., Sun, S. Y., Franchim, C. S., and Mattar, R. (2011). Polymorphisms in VEGF, progesterone receptor and IL1 receptor genes in women with recurrent spontaneous abortion. $J$. Reprod. Immunol. 88, 53-57.

Tsai, A. F., Kaufman, K. A., Walker, M. A., Karrison, T. G., Odem, R. R., Barnes, R. B., Scott, J. R., Schreiber, J. R., Stephenson, M. D., and Ober, C. (1998). Transmission disequilibrium of maternally-inherited CTLA4 microsatellite alleles in idiopathic recurrent miscarriage. J. Reprod. Immunol. 40, 147-157.

Unfried, G., Schneeberger, C., Szabo, L. Nagele, F., Huber, J. C., and Tempfer, C. B. (2001). Tryptophan hydroxylase gene polymorphism (A218C) and idiopathic recurrent miscarriage. Obstet. Gynecol. 98, 664-667.

Uuskula, L., Rull, K., Nagirnaja, L., and Laan, M. (2011). Methylation allelic polymorphism (MAP) in chorionic gonadotropin beta5 (CGB5) and its association with pregnancy success. J. Clin. Endocrinol. Metab. 96, E199E207.

Van den Veyver, I. B. (2001). Skewed $\mathrm{X}$ inactivation in X-linked disorders. Semin. Reprod. Med. 19, 183-91.

Vanniarajan, A., Govindaraj, P., Carlus, S. J., Aruna, M., Aruna, P., Kumar, A., Jayakar, R. I., Lionel, A. C., Gupta, S., Rao, L., Gupta, N. J., Chakravarthy, B., Deenadayal, M., Selvaraj, K., Andal, S., Reddy, B. M., Singh, L., and Thangaraj, K. (2011). Mitochondrial DNA variations associated with recurrent pregnancy loss among Indian women. Mitochondrion 11, 450-456.

von Linsingen, R., Bompeixe, E. P., and Bicalho Mda, G. (2005). A casecontrol study in IL6 and TGFB1 gene polymorphisms and recurrent spontaneous abortion in southern Brazilian patients. Am. J. Reprod. Immunol. 53, 94-99.

Walch, K., Riener, E. K., Tempfer, C. B., Endler, G., Huber, J. C., and Unfried, G. (2005). The C46T polymorphism of the coagulation factor XII gene and idiopathic recurrent miscarriage. BJOG 112 , 1434-1436.
Wang, X., Lin, Q., Ma, Z., Hong, Y., Zhao, A., Di, W., and Lu, P. (2005). Association of the $\mathrm{A} / \mathrm{G}$ polymorphism at position 49 in exon 1 of CTLA4 with the susceptibility to unexplained recurrent spontaneous abortion in the Chinese population. Am. J. Reprod. Immunol. 53, 100-105.

Warburton, D., Kline, J., Kinney, A., Yu, C. Y., Levin, B., and Brown, S. (2009). Skewed X chromosome inactivation and trisomic spontaneous abortion: no association. Am. J. Hum. Genet. 85, 179-193.

Witt, C. S., Goodridge, J., GerbaseDelima, M. G., Daher, S., and Christiansen, F. T. (2004). Maternal KIR repertoire is not associated with recurrent spontaneous abortion. Hum. Reprod. 19, 2653-2657.

Wramsby, M. L., Sten-Linder, M., and Bremme, K. (2000). Primary habitual abortions are associated with high frequency of factor $\mathrm{V}$ Leiden mutation. Fertil. Steril. 74, 987-991.

Yenicesu, G. I., Cetin, M., Ozdemir, O., Cetin, A., Ozen, F., Yenicesu, C., Yildiz, C., and Kocak, N. (2009). A prospective case-control study analyzes 12 thrombophilic gene mutations in Turkish couples with recurrent pregnancy loss. Am. J. Reprod. Immunol. 63, 126-136.

Yu, X. W., Li, X., Ren, Y. H., and Li, X. C. (2007). Tumour necrosis factoralpha receptor 1 polymorphisms and serum soluble TNFR1 in early spontaneous miscarriage. Cell Biol. Int. 31, 1396-1399.

Yuen, R. K., Avila, L., Penaherrera, M. S., von Dadelszen, P., Lefebvre, L., Kobor, M. S., and Robinson, W. P. (2009). Human placentalspecific epipolymorphism and its association with adverse pregnancy outcomes. PLoS ONE 4, e7389. doi:10.1371/journal.pone.0007389

Zechner, U., Pliushch, G., Schneider, E., El Hajj, N., Tresch, A., Shufaro, Y., Seidmann, L., Coerdt, W., Muller, A. M., and Haaf, T. (2009). Quantitative methylation analysis of developmentally important genes in human pregnancy losses after ART and spontaneous conception. Mol. Hum. Reprod. 16, 704-713.

Zhang, S., Wang, J., Wang, B., Ping, Y., and Ma, X. (2011). Strong association between angiotensin Iconverting enzyme I/D polymorphism and unexplained recurrent miscarriage of Chinese women - a case-control study. Reprod. Sci. 18, 743-746.

Zusterzeel, P. L., Nelen, W. L., Roelofs, H. M., Peters, W. H., Blom, H. J., and Steegers, E. A. (2000). Polymorphisms in biotransformation 
enzymes and the risk for recurrent early pregnancy loss. Mol. Hum. Reprod. 6, 474-478.

Conflict of Interest Statement: The authors declare that the research was conducted in the absence of any commercial or financial relationships that could be construed as a potential conflict of interest.

Received: 29 January 2012; paperpending published: 16 February 2012; accepted: 24 February 2012; published online: 19 March 2012.
Citation: Rull K, Nagirnaja L and Laan $M$ (2012) Genetics of recurrent miscarriage: challenges, current knowledge, future directions. Front. Gene. 3:34. doi 10.3389/fgene.2012.00034

This article was submitted to Frontiers in Epigenomics, a specialty of Frontiers in Genetics.
Copyright (C) 2012 Rull, Nagirnaja and Laan. This is an open-access article distributed under the terms of the Creative Commons Attribution Non Commercial License, which permits non-commercial use, distribution, and reproduction in other forums, provided the original authors and source are credited. 